\title{
Sovereign Bond Volatility versus Stock Volatility: Evidence from Ghana
}

\author{
William Mawuli K. Adjimah \\ Institute of Distance Learning \\ Kwame Nkrumah University of Science and Technology \\ Kumasi, Ghana \\ Charles Nsiah \\ Finance Office \\ Kwame Nkrumah University of Science and Technology \\ Kumasi, Ghana \\ Felix Obeng Boateng \\ Finance Office \\ Kwame Nkrumah University of Science and Technology \\ Kumasi, Ghana
}

\begin{abstract}
In this paper, we examine return volatility in the sovereign domestic/foreign bond and stock markets in Ghana using ratios, correlation, ARCH/GARCH family models. The study considered daily returns covering periods from $1^{\text {st }}$ May $2009-31^{\text {st }}$ July 2018. We find that even though the bond market volatility has increased relatively over time, it is less volatile as compared to the stocks. More so, bonds are still an effective diversification medium as a result of nonexistence of trend in the correlation between bond and stock and the ratio of the bond to the stock. We show that the trend in volatility for Ghana Domestic Bond $(G D B)$ and stock markets are negatively significant. Furthermore, we document that the ARCH model can be used to predict future values in the domestic bond return series. However, it cannot be used to predict future values in the Ghana Foreign Bond (GFB) and Stock daily return series.
\end{abstract}

Keywords: Volatility, Bond Market, Stock Market, Asset Allocation, ARCH, GARCH. JEL Classification: G11, G17

\section{Introduction}

Volatility is seen as information flow in several classes of models (Jones, Lamont and Lumsdaine, 1998) and its analysis is crucial to the practice and theory of risk management, asset allocation and asset pricing (Andersen et al., 2001). This has stimulated vibrant and burgeoning research into the return volatility physiognomies of stock and bond markets over three decades now.

Sovereign debt in Sub-Saharan Africa (SSA) over the last decade has witnessed profound changes after having enjoyed a "clean slate" through the Multilateral Debt Relief Initiative (MDRI) and the successors of debt relief under the Heavily Indebted Poor Country (HIPC) initiative (Dafe, Essers and Volz, 2018; Senga, Cassimon and Essers, 2018). In the zeal to boot external financing conditions, mitigate currency mismatches and address the huge infrastructural and social needs. Many ex-HIPC countries have documented a rise in sovereign debt to GDP ratios which has become a changing trend (Dafe, Essers and Volz, 2018).

It is widely believed that there is an exciting investor hunger for SSA bonds and stocks (Senga, Cassimon and Essers, 2018). This is fueled by the global financial crises aftermath of commodity price recovery, and all-time low record of interest rate in developed economies. Presbitero et al., (2016) showed that developing and low-income countries are probably going to issue more international bonds (Eurobonds) should the US interest rate remain low. Notwithstanding the potential advantages of diversified debt, there are also some risks particularly for African countries sovereign Eurobonds (henceforth, foreign bonds). This is because they are denominated in US dollars which could lead to adverse pressure on the exchange rates and country's foreign reserves when payments are due (Olabisi and Stein, 2015; Senga, Cassimon and Essers, 2018). Studies by Olabisi and Stein (2015) have also documented the high cost of borrowing as part of sovereign debt burden and can contribute to return volatility and future risk of default. Likewise, there have been alarming cases of a deficit in government budgets and instability in the macroeconomic framework since 2014 through to 2016 in Angolo, Ghana and Zambia with noticeable consequences on domestic and foreign bond markets (Senga and Cassimon, 2018) which may spillover on other markets like stocks. 
Whereas many earlier studies have compared bond and stock market volatility in developed markets. The volatility patterns exhibited in developing and less-income economies has not been broadly studied. In the light of providing such perspective, and convinced that the bond versus stock dispersions are not globally universal. We ask the question: do the bond and stock market volatility in developing markets change over time? More specifically, how is the relative change of the bond to the stock volatility in developing markets? How predictable are the volatility patterns in the bond and stock markets in developing markets? In seeking answers to these questions, we employ dataset from Ghana and analyze intertemporal volatility between sovereign bond returns (domestic and foreign) and stocks return over 9 years.

We focus on Ghana because Moody's has recently affirmed the Government of Ghana's long-term issuer and senior unsecured bond ratings at B3 (Moody's, 2020). Thus, changing the outlook from stable to positive. Therefore, informing on the asset allocation effects between bond and stock markets seems interesting.

The contribution of this study to the existing literature is twofold. First, by comparing and examining bond and stock return volatility within the Ghana market, we sought to give investors intuition into the investing merits and future return predictability of either bonds or stocks relatively. Second, it complements the existing literature which focuses on developed economies (see: Reilly, Wright and Chan, 2000; Johnson and Young, 2002; Jones and Wilson, 2004; Young and Johnson, 2004).

The rest of the paper proceeds in the following manner. Section 2 provides a brief review of relevant literature. Section 3 defines the data source for the study. Section 4 outlines the methodology employed. Section 5 presents the results of this study with the conclusion presented in section 6 .

\section{Literature}

The literature on stock and bond market volatility has been extensively documented dating back to the 1970s (see e.g., Fisher and Lorie, 1970; Officer, 1973; Sharpe, 1973). Empirically, the evidence about bond market volatility versus stock market volatility is mixed at best. Among the extant works, Reilly, Wright and Chan (2000) found that volatility of the US bond market increased relative to the volatility of the stock market. They further showed that the autoregressive conditional heteroscedasticity $(\mathrm{ARCH}(1))$ model could be employed to predict the bond market volatility but not the stock volatility. Evidence from Swiss and UK markets showed different volatility patterns in bond/stock standard deviations. For example, Young and Johnson (2004) found a negative correlation between bonds and stocks and nonexistence of trend in the bond/stock standard deviations ratio. They again indicated that there was an increase over time in the effectiveness of Swiss bond as diversification vehicles. Their study employed the generalized autoregressive conditional heteroscedasticity $(\operatorname{GARCH}(1,1))$ model. These findings are consistent with evidence by Johnson and Young (2002) who found that over 30-year, the volatility of the UK stock market was about twice the average volatility of the bond market. Jones and Wilson (2004) also found that the relative change in the bond volatility and stock volatility was even more pronounced when inflation was considered.

More recently, Bessembinder (2018) examined the Center for Research in Security Prices (CRSP) database from 19262016. He shows that the majority of returns earned on US common stock is less than that of the relative treasury bill return in the long-run horizon. Liu, Wang and $\mathrm{Li}$, (2019) in their findings also revealed that the impact of negative shocks had little effect on US treasury cash market. But causes asymmetric volatility effects in US treasury bond futures market and US stock. Their research used the VEC Copula GJR-GARCH Skewed-Student-t model.

Several studies have shown that bond volatility encrypts valued information concerning the financial market and the state of the economy (Pan and Chan, 2018). Bretscher, Schmid and Vedolin (2016) for example show that the slowdown at the firm level and market future economic activities is positively related to treasury bond volatility. Creal and $\mathrm{Wu}(2014)$ also found that higher volatility of treasury bond also leads to a higher rate of unemployment. Arnold and Vrugt (2010) employed the GARCH in their study found that an increase in one standard deviation in macroeconomic uncertainty (measures of real activities, inflation and monetary policy rate) lead to about 20-50 basis points in the volatility of bond market quarterly.

Another applied area of research that has received substantial attention in the literature is the analysis of the properties of volatility indices in international markets. In particular, López (2015) showed that changes in Treasury bond volatility indices were positively correlated with the European equity-based volatility indices and both US non-fixed income and Treasury yield rates. Some interesting facts include a significant dynamic and contemporaneous relationship between international equity-based volatility (see e.g., Äijö, 2008; Konstantinidi, Skiadopoulos and Tzagkaraki, 2008; Siriopoulos and Fassas, 2012), a negative contemporaneous relationship among underlying stock indices return and changes in volatility indices (see e.g., Giot, 2005; Gonzalez and Alfonso, 2009; Whaley, 2009) and the rise or fall of volatility indices following news on macroeconomic fundamentals (see e.g., Castanias II, 1979; Jones, 
Lin and Masih, 2005; Rapach, Wohar and Rangvid, 2005; Äijö, 2008; Arnold and Vrugt, 2008; Konstantinidi, Skiadopoulos and Tzagkaraki, 2008; Siriopoulos and Fassas, 2012; Creal and Wu, 2014; Su, Fang and Yin, 2018; Segal, 2019).

While most of the research on bond market volatility has been examined using developed markets, there is some documented literature on stocks volatility in developing markets. For instance, Gbeda and Peprah (2018) found that contrary to the Nairobi Stock Exchange, there is no evidence of conditional volatility in daily prices and return information on the Ghana Stock Exchange. Adjasi (2009) also analyzed the stock price volatility in Ghana based on macroeconomic uncertainty using the EGARCH. He shows that stock volatility resulted from higher interest rates and cocoa price volatility, whilst higher volatility in money supply, oil prices and gold prices reduced stock volatility. Other works on stock market volatility have also been documented (see examples, Alagidede and Panagiotidis, 2006; Frimpong and Oteng-Abayie, 2006; Jaramba and Fadiran, 2009; Angko, 2013; Lin, Wesseh and Appiah, 2014; Saleem et al., 2014; King and Botha, 2015).

In the case of bonds, we are not aware of any studies on bond return volatility in Africa. Existing research focuses on regional cases of either foreign bonds (see e.g., Mecagni et al., 2014; Olabisi and Stein, 2015; Gevorkyan and Kvangraven, 2016; Presbitero et al., 2016; Senga, Cassimon and Essers, 2018) or domestic bonds (see e.g., Adelegan and Radzewicz-Bak, 2009; Mu, Phelps, \& Stotsky, 2013; Essers, 2014; Dafe, Essers and Volz, 2018). This study analysis volatility conditions in the sovereign bond market and compares it to the stock market in Ghana.

\section{Data}

For our first dataset, we focus on monthly sovereign bond return volatility computed for both foreign currency and local currency-denominations using daily returns between $1^{\text {st }}$ May 2009 to $31^{\text {st }}$ July 2018 periods from the S\&P Ghana Sovereign Bond index and compare their intertemporal deviations with that of the stock return volatility. S\&P Ghana Sovereign Bond index was launched in November 2014 as part of S\&P Dow Jones Indices which is also a division of S\&P Global. All data presented is back-tested before the date of the index lunch. On the other hand, our second data (stock) was sourced from the Ghana Stock Exchange Composite (GSEC) Index which is well specified and fairly comprehensive over the same period. Finally, we explore time-varying heteroscedasticity dynamics for stocks, foreign and domestic bond using daily returns series.

\section{Methodology}

To examine volatility between the bond and stock markets, we compute 1) 3-month moving standard deviation of the monthly rate of return. ${ }^{1}$ 2) discrete standard deviation of the monthly rate of return. 3) ratio of 3-month moving standard deviation of the monthly rate of return for bond relative to the stock. 4) discrete ratio of the monthly standard deviation of the rate of return for bond relative to the stock. 5) 3-month moving correlation between Ghana sovereign bond and stock return. Lastly, we explore volatility clustering properties in daily return series for the Ghana sovereign bond and stock markets over the period measured.

\subsection{Stationarity test}

To examine the stationarity of the bond and stock daily return series and to evaluate the persistence of shocks, we employ the Dickey-Fuller (DF), Augmented Dickey-Fuller (ADF) (Dickey and Fuller 1979, Fuller 1976) and PhillipsPerron (PP) test for the null hypothesis of a unit root in the series, contrary to the one-sided alternate stationarity in series. This is because if a series is non-stationary, the asymptotic analysis for the standard assumptions will not be valid or not follow a t-distribution.

\subsection{Univariate volatility models}

Volatility clustering is a characteristic feature of financial data. This could be interpreted as a clustering of the error term's variance over time. In other words, if the variance tends to be large (small) in one period, it tends to be small (large) in the next. Volatility clustering is indicative of time-varying heteroscedasticity (Engle, 2001). Two well-known models of volatility clustering in literature are the autoregressive conditional heteroscedasticity (ARCH) model of Engle (1982) and Generalized ARCH (GARCH) model of Bollerslev (1986). The study will employ these classical models to analysis volatility clustering in the bond/stock daily series.

The standard ARCH model takes the form:

$$
y_{t}=\emptyset_{0}+\emptyset_{1} y_{t-1}+u_{t}
$$

\footnotetext{
${ }^{1}$ We estimate monthly volatility as the standard deviation of daily return within that month. We also mitigate the effects of possible mechanical return skewness by using log returns.
} 
where $y_{t}=$ daily stock or bond return, $\emptyset_{0}=$ intercept term, $\emptyset_{1}=$ lag one period estimated coefficient for stock and bond daily return, and $u_{t}=$ error term characterized with ARCH, thus, $u_{t} \sim F\left(0, \sigma_{t}^{2}\right)$ and for "p" periods of lags

$$
\sigma_{t}^{2}=\alpha_{0}+\alpha_{1} u_{t-1}^{2}+\alpha_{2} u_{t-2}^{2}+\cdots+\alpha_{p} u_{t-p}^{2}
$$

with $0 \leq \sum_{i=1}^{p} \alpha_{i}<1$ and $\alpha_{0}, \alpha_{i} \geq 0$. However, the $\mathrm{ARCH}(4)$ specification might be reasonably approximated by a $\operatorname{GARCH}(1,1)$. The simplest form is represented as:

$$
\sigma_{t}^{2}=\alpha_{0}+\alpha_{1} u_{t-1}^{2}+\beta_{1} u_{t-2}^{2}
$$

with $0 \leq \alpha_{1}+\beta_{1}<1$ and $\alpha_{0}, \alpha_{1} \geq 0, \beta_{1} \geq 0$

\section{Result analysis}

\subsection{Descriptive Statistics}

In Table 1, we present the descriptive statistics of the daily returns of the Ghana stock and bond market over the period measured. We show that the average daily returns of the stock, domestic bond and foreign bond markets are 7.715, 5.660 and 5.110 respectively. The daily deviation for stock returns is about $60.42 \%$, while that of the domestic and foreign bonds are about $50.10 \%$ and $16.89 \%$ respectively. Additionally, in terms of the skewness, the distribution for the stock and domestics bond returns are skewed to the right, while the distribution for the foreign bond return is negatively skewed. Again, we note that the daily stock yield is leptokurtic. Thus, the observations are closer to the mean and more peaked than the normal distribution. However, the domestic bond daily return is platykurtic since the kurtosis value is less than 3 . Thus, observations scatter widely about the mean.

Table 1 Descriptive statistics of daily returns of Ghana stocks and bond market between May 2009 to July 2018

\begin{tabular}{lrrr} 
& \multicolumn{1}{c}{ Stock } & \multicolumn{1}{l}{ GDB } & \multicolumn{1}{l}{ GFB } \\
\hline Observation & 2,277 & 2,406 & 2,406 \\
Minimum & 6.8459 & 4.6057 & 4.6057 \\
Maximum & 13.6234 & 6.5729 & 5.4493 \\
Mean & 7.7146 & 5.6604 & 5.1101 \\
Std. Dev. & 0.6042 & 0.5010 & 0.1689 \\
Variance & 0.3650 & 0.2510 & 0.0285 \\
Skewness & 1.1587 & 0.1567 & -0.5744 \\
Kurtosis & 7.8086 & 2.1241 & 3.2198 \\
\hline
\end{tabular}

Authors' Computation, using STATA 14.2.

Note: GDB= Ghana Domestic Bond, GFB = Ghana Foreign Bond

\subsection{Analysis of monthly Ghana Domestic Bond (GDB) market volatility}

Panel A in Figure 1 displays the plot of a 3-month moving standard deviation of monthly return for GDB from May 2009 - July 2018 periods. We see that there are some significant peaks at about $4.9 \%$ in August 2009, increasing significantly to about $7.0 \%$ in September 2009 and then declines slightly to about $3.7 \%$ in December 2009. Return volatility peaked up again at about 4.9\% rising to 5.2\% in April 2010 and May 2010 respectively. January 2013 recorded the most substantial volatility peak in domestic bond return when about $8.6 \%$ volatility was reached. There are also noticeable volatile peaks at about 8.0\%, 6.7\% and 5.2 in December 2012, November 2012 and March 2013 respectively. August 2013 saw the lowest volatility return, with some sluggish trough at about $0.2 \%-0.3 \%$ from May 2011 - July 2011. The test for 9-year trend in the GDB volatility is negatively significant at a 1\% confidence level $(t=-$ 2.74). Implying that GDB volatility seems to be decreasing. The list of the summary statistics of the ten lowest and highest volatility range for the GDB is shown in Table 2. The current mean of monthly standard deviation yield is about $0.7 \%$, while the GDB annual standard deviation of monthly return is about $5.7 \%$. 
Table 2 Summary Statistics for Ghanaian Sovereign Bond and Stock market return indexes: Monthly Standard Deviations of Daily Returns: $1^{\text {st }}$ May 2009-31 ${ }^{\text {st }}$ July 2018

\section{A. High Volatility}

\begin{tabular}{|c|c|c|c|c|c|}
\hline \multicolumn{2}{|c|}{ Domestic Bond Market } & \multicolumn{2}{|c|}{ Foreign Bond Market } & \multicolumn{2}{|c|}{ Stock Market } \\
\hline Months & $\begin{array}{c}\text { Monthly Std. Dev. } \\
(\%)\end{array}$ & Months & $\begin{array}{c}\text { Monthly Std. Dev. } \\
(\%)\end{array}$ & Months & $\begin{array}{c}\text { Monthly Std. Dev. } \\
(\%)\end{array}$ \\
\hline Jan-13 & 3.080 & Jul-15 & 8.694 & Oct-11 & 142.313 \\
\hline Jul-09 & 2.795 & Sep-14 & 7.586 & Mar-11 & 141.923 \\
\hline Sep-14 & 2.135 & Mar-17 & 4.085 & Jun-09 & 11.126 \\
\hline May-12 & 2.129 & Aug-15 & 3.614 & May-09 & 5.961 \\
\hline Feb-14 & 2.106 & Feb-14 & 3.532 & Jan-18 & 5.842 \\
\hline Jun-09 & 1.809 & Aug-14 & 3.446 & Jul-17 & 5.389 \\
\hline Oct-09 & 1.546 & Jan-13 & 2.954 & Mar-13 & 4.816 \\
\hline Mar-10 & 1.484 & Jul-09 & 2.711 & Feb-13 & 4.558 \\
\hline Jul-12 & 1.425 & Mar-15 & 2.695 & Oct-09 & 4.476 \\
\hline Jan-10 & 1.415 & Apr-12 & 2.655 & Jun-18 & 3.364 \\
\hline
\end{tabular}

B. Low Volatility

\begin{tabular}{|c|c|c|c|c|c|}
\hline \multicolumn{2}{|c|}{ Domestic Bond Market } & \multicolumn{2}{|c|}{ Foreign Bond Market } & \multicolumn{2}{|c|}{ Stock Market } \\
\hline Months & $\begin{array}{l}\text { Monthly Std. Dev. } \\
(\%)\end{array}$ & Months & $\begin{array}{l}\text { Monthly Std. Dev. } \\
\text { (\%) }\end{array}$ & Months & $\begin{array}{l}\text { Monthly Std. Dev. } \\
(\%)\end{array}$ \\
\hline Dec-11 & 0.179 & May-10 & 0.116 & Nov-13 & 0.228 \\
\hline Мay-18 & 0.190 & Nov-10 & 0.249 & Jul-16 & 0.292 \\
\hline Nov-11 & 0.193 & Dec-12 & 0.271 & Jan-16 & 0.323 \\
\hline Feb-18 & 0.196 & Apr-18 & 0.309 & Oct-15 & 0.352 \\
\hline Oct-11 & 0.215 & Feb-12 & 0.315 & Jan-12 & 0.353 \\
\hline Feb-11 & 0.238 & Oct-10 & 0.320 & Jun-15 & 0.360 \\
\hline Aug-13 & 0.244 & Dec-11 & 0.322 & Aug-12 & 0.380 \\
\hline Mar-12 & 0.263 & Jun-12 & 0.325 & Dec-13 & 0.387 \\
\hline Jul-14 & 0.275 & Feb-13 & 0.332 & Feb-15 & 0.388 \\
\hline Apr-18 & 0.282 & Apr-15 & 0.358 & Sep-12 & 0.408 \\
\hline \multicolumn{6}{|c|}{ C. Statistics for Entire Period: May 2009- July 2018} \\
\hline \multicolumn{3}{|c|}{ Domestic Bond Market (\%) } & \multicolumn{2}{|c|}{$\begin{array}{c}\text { Foreign Bond Market } \\
(\%)\end{array}$} & Stock Market (\%) \\
\hline \multicolumn{3}{|c|}{$\begin{array}{l}\text { Mean of Monthly Standard Deviations }(\mathrm{N}=111) \\
0.716\end{array}$} & \multicolumn{2}{|c|}{1.310} & 4.085 \\
\hline \multicolumn{3}{|c|}{ Mean of Yearly Standard Deviations (N=9) 5.722} & \multicolumn{2}{|c|}{6.449} & 14.180 \\
\hline
\end{tabular}


Figure 1 Moving 3-month standard deviations of Ghana sovereign bond (GDB and GFB) and stock markets monthly rate of returns from May 2009 - July 2018
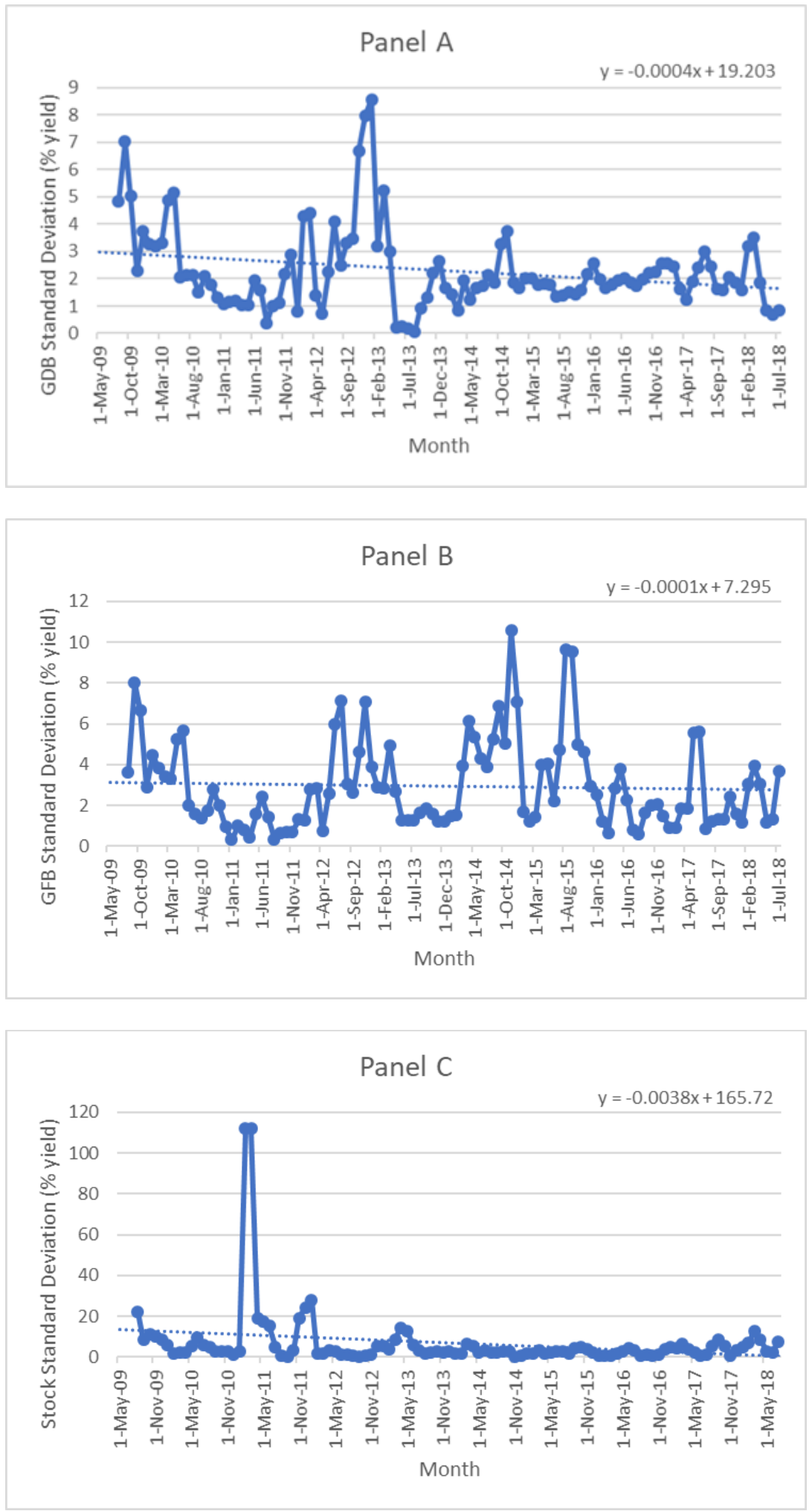

Note: For Panel A and B, data is computed from the S\&P Ghana Sovereign Bond Index daily returns. Whiles Panel C is computed from the Ghana Stock Exchange Composite (GSEC) Index daily returns. 


\subsection{Analysis of monthly Ghana Foreign Bond (GFB) market volatility}

Similarly, the 3-month moving standard deviation of the monthly rate of return plot for GFB is shown in Figure 1(B). We show that the foreign bond seems to be a bit more volatile than domestic bonds. The most substantial volatility spike is in November 2014 (10.6\%) followed by August/September 2015 and September 2009 when about 9.6\% and $8.0 \%$ volatility were reached respectively. July 2012, November 2012 and December 2014 also recorded peaks of about 7.1\%. There is also noticeable significant volatility at about 6.9\%, 6.7\% and 6.1\% in September 2014, October 2009, and April 2014 respectively. However, January 2011 saw the lowest volatility of foreign bond return of about $0.3 \%$ with some slow trough between $0.4 \%-1 \%$. The test for 9-year trend in the GFB volatility is insignificant $(t=-0.47)$. As captured again in Panel $\mathrm{C}$ of Table 2, the average monthly standard deviation for the GFB is about $1.3 \%$. However, the annual standard deviation of monthly return of about 6.5\%. Indicating that GFB return is more volatile compared to the GDB return series. In all, the annual volatility pattern in the Ghana sovereign bond markets is higher compared to $1.3 \%$ in Switzerland (reported by Young and Johnson, 2004), 2.8\% in the UK (reported by Johnson and Young, 2002) and $1.2 \%$ in the US (reported Reilly, Wright and Chan, 2000).

\subsection{Analysis of monthly stock market volatility}

Figure 1(C), graphs the 3-month moving standard deviation for the stock series for the May 2009 - July 2018 periods. Starting from August 2009, there is a high peak of about 22.1\%, which then declined to about 8.4\% in September 2009 and increased again to about $11.0 \%$ in October 2009. The most substantial volatility peak in stock return occurred in February and March 2011 where at $111.8 \%$ and $111.9 \%$ spikes were reached. Other spikes are also documented at about 19.2\% (November 2011), 24.4\% (December 2011) and 27.9\% (January 2012).

However, minor volatility peaks are seen around September 2012, November 2014 and September 2011. The test for 9year trend in the Ghana stock volatility is negatively significant at a $1 \%$ confidence level $(t=-2.50)$.

Comparing Ghana stock to the bond market, it is obvious that the stock patterns are more volatile than the bond. Again, volatility concentration in the stock also differs from both GDB and GFB asset classes. The lowest (ascending) and highest (descending) discrete average monthly standard deviation of stock returns relative to the GDB and GFB are presented in Panel A and B of Table 2. We see that the highest and lowest top 10 monthly volatility in the stock occurs at different months to the GFB volatility. The same is also seen for the GDB volatility to the stock volatility except for June 2009 and October 2009 which appear within the first ten highest (even that the spike level is higher in the stock). The average monthly standard deviation for stock return (Panel C of Table 1) is about three times the GFB (4.0854 versus 1.310) and about five and a half times the GDB (4.0854 versus 0.7158$)$. However, the average annual standard deviation for stock (14.180) is about two and a half times the average annual standard deviation for GDB (5.722\%) and GFB (6.449\%).

Young and Johnson (2004:12) reported thrice (4.484 versus 1.249) for Swiss stock versus bond markets, Johnson and Young (2002: 105) reported twice (5.377\% versus 2.755\%) in the UK, while Reilly, Wright and Chan (2000:85) reported 3.7835 versus 1.770 for the US stock versus bond markets. In terms of annual standard deviation percentile levels, volatility percentage in the Ghana stock and bond market appears to be higher. Suggesting that volatility patterns observed from the Ghanaian stock and bond market are higher compared to those in the developed market.

\subsection{Ratio of Bond volatility to Stock volatility}

The ratio of moving 3-month standard deviation of GDB to the stock is graphed in Figure 2(A). It shows clearly that the volatility relationship between the GDB and stock is not stable and ranges from 0.029 to 1.66 in the ratio. Whereas volatility in the stock is generally higher, there were several months within the 9 years when the stock volatility was lower than GDB (signified by a ratio over 1.0). The trend in the ratio of volatility over time has a slope coefficient of about 0.0000332 ( $\mathrm{p}=0.356$ ), implying that GDB returns are insignificantly volatile compared to the stock market. This supports findings by Johnson and Young (2002) and Young and Johnson (2004) who establish no relationship among the bond and stock volatility ratio for the UK and Swiss markets respectively. 
Figure 2 Ratio of Moving 3-Month Standard Deviation of Returns for Ghana Sovereign Bond (GDB and GFB) to Stock from May 2009 - July 2018
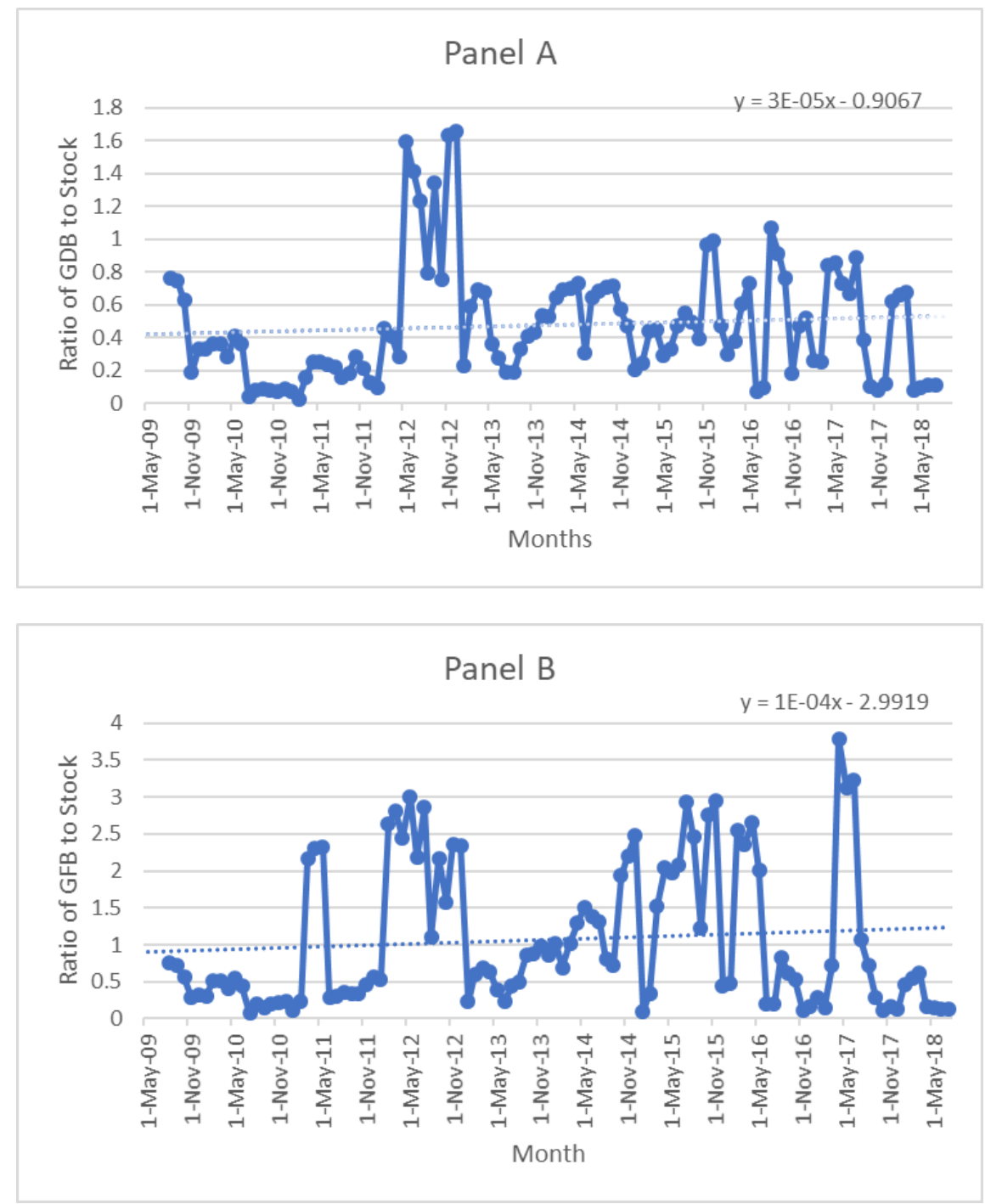

This is also confirmed by the summary statistics of the discrete ratio of monthly standard deviation for GDB to stock as presented in Table 3 (list 10 highest and lowest volatility ratio). The ratio of volatility is significantly substantial and ranges from a low of about 1/663rd (0.002) in October 2011, to a high of about 3 and half times (3.455) in September 2012. In terms of concentration, the highest monthly ratio of volatility started in April 2012, with about 5 out of the top 10 highest ratio volatility captured within 2012. Also, in the case of low volatility concentrations, 5 out of the 10 low months were all below 2012 while the rest were above 2011. Averagely, the monthly GDB volatility pattern is about 0.749 to the stock volatility. The mean of the annual ratio of GDB volatility to stock volatility is also about 0.7550 . Implying that the Ghana domestic bond market volatility on the average exhibit about $3 / 4^{\text {th }}$ of the annual stock market volatility over the period measured. 
Table 3 Summary Statistics of Bond Volatility Versus Stock Volatility for May 2009 - July 2018

A. High Volatility Ratio

\begin{tabular}{cccc}
\hline Months & Ratio of Std. Dev. GDB/Stock & Months & Ratio of Std. Dev. GFB/Stock \\
\hline Sep-12 & 3.4555 & Mar-17 & 7.633 \\
Aug-12 & 3.4479 & Aug-15 & 6.838 \\
Apr-12 & 3.2221 & Apr-12 & 6.156 \\
Jul-16 & 2.3776 & Jan-16 & 5.987 \\
May-12 & 2.1427 & Jun-15 & 5.784 \\
Jul-12 & 2.1416 & Sep-14 & 5.314 \\
Oct-15 & 2.1014 & Jan-12 & 5.119 \\
Mar-17 & 1.8616 & Aug-12 & 4.755 \\
May-17 & 1.8471 & Sep-12 & 4.576 \\
Feb-14 & 1.7377 & Jul-15 & 4.402 \\
\multicolumn{5}{c}{ Months } & \\
B. Low Volatility Ratio & Ratio of Std. Dev. GFB/Stock \\
\hline Months & Ratio of Std. Dev. GDB/Stock & Mar-11 & 0.003 \\
\hline Oct-11 & 0.0015 & Oct-11 & 0.008 \\
Mar-11 & 0.0023 & May-10 & 0.049 \\
May-18 & 0.0646 & Feb-13 & 0.073 \\
Jul-17 & 0.0795 & Jul-17 & 0.089 \\
Feb-13 & 0.0923 & Jun-10 & 0.114 \\
Feb-18 & 0.0926 & Dec-12 & 0.123 \\
Jun-10 & 0.0940 & Jun-09 & 0.133 \\
Dec-11 & 0.1189 & Nov-10 & 0.164 \\
Jun-18 & 0.1340 & May-09 & 0.172 \\
May-10 & 0.1466 & & \\
Mean of Monthly Ratio of GDB Std. Dev. to Stock Std. Dev. = 0.7488 & \\
Mean of Monthly Ratio of GFB Std. Dev. to Stock Std. Dev. = 1.4547 & \\
Mean of Yearly Ratio of GDB Std. Dev. to Stock Std. Dev. = 0.7550 & \\
Mean of Yearly Ratio of GFB Std. Dev. to Stock Std. Dev. = 0.9514 & \\
\hline
\end{tabular}

Similarly, the relationship between the ratio of the GFB volatility to the stock is also not stable. As graphed in Figure 2B, there are several periods when the 3-month moving deviation of the GFB was again more volatile than the stock (signified by a ratio over 1.0), fluctuating between 0.0684 (July 2010) and 3.793 (April 2017). However, the leastsquares trending slope coefficient is insignificant $(0.0000975, \mathrm{p}=0.324)$, indicating that the increase in the GFB volatility was also less to the stock volatility.

Table 3 presents a summary of the discrete calendar month ratio with the highest and lowest volatility relationship between these two asset markets. The average month GFB standard deviation to stock standard deviation is 1.4547. However, the mean annual ratio of GFB volatility to stock is about 0.9514 . Implying that, passably, the annual GFB market volatility has been increasing about the same times as the annual volatility of the stock market within the period measured. Studies by Young and Johnson (2004, p. 14) found that "bond market in Switzerland exhibits less than onethird the volatility of the stock market" (Reilly, Wright and Chan (2000) found similar results) whiles Johnson and Young (2002, p. 106) found "bond market exhibits roughly half the volatility of the stock market".

To ascertain the variations in the ratio of volatility over time, we examine the monthly variances of stock and bond returns during a yearly period. The results in Table 4 show the ratio of stock variance to the GDB and GFB for each year. In the case of stock variance to GDB variance, the differences in variance follow an up and down pattern, increasing significantly to about 110906 in 2011 and declining sharply to 0.6 (2014) before rising again to about 18 (2018). The F-test of the stock variance to GDB variance shows that two (2012 and 2014) out the 9-years are not significant. However, stocks remain more volatile compared to GDB. Similarly, in the case stock variance to the GFB variance, there is a steep rise to about 13403 in 2011 and sharply declined between 2012 and 2017 (i.e., from 0.06 to 1.8) before increasing again to about 11 (2018). 
Table 4 Monthly Return Variances of Sovereign Bonds and Stocks for May 2009 -July 2018

\begin{tabular}{|c|c|c|c|c|c|}
\hline \multirow[b]{2}{*}{ Year } & \multicolumn{3}{|c|}{1 Year Return Variance } & \multirow{2}{*}{$\begin{array}{c}\text { Ratio of Stock } \\
\text { Variance to GDB } \\
\text { Variance }\end{array}$} & \multirow{2}{*}{$\begin{array}{c}\text { Ratio of Stock } \\
\text { Variance to GFB } \\
\text { Variance }\end{array}$} \\
\hline & $\begin{array}{c}\text { GDB } \\
\text { Returns }\end{array}$ & $\begin{array}{c}\text { GFB } \\
\text { Returns }\end{array}$ & Stock Returns & & \\
\hline 2009 & 0.520 & 0.463 & 12.230 & $23.520(0.0006)$ & $26.439(0.0001)$ \\
\hline 2010 & 0.178 & 0.265 & 0.729 & $40.100(0.0138)$ & $2.756(0.0536)$ \\
\hline 2011 & 0.027 & 0.224 & 3010.544 & $110906.029(4.31 \mathrm{E}-26)$ & $13430.080(4.75 \mathrm{E}-21)$ \\
\hline 2012 & 0.361 & 0.749 & 0.411 & $1.139(0.4164)$ & $0.549(0.1675)$ \\
\hline 2013 & 0.573 & 0.574 & 2.441 & $4.263(0.0119)$ & $4.252(0.0120)$ \\
\hline 2014 & 0.406 & 3.850 & 0.233 & $0.573(0.1847)$ & $0.060(0.0000)$ \\
\hline 2015 & 0.034 & 5.148 & 0.420 & $12.379(0.0001)$ & $0.082(0.0001)$ \\
\hline 2016 & 0.034 & 0.390 & 0.881 & $25.629(3.01 \mathrm{E}-06)$ & $2.262(0.0958)$ \\
\hline 2017 & 0.115 & 1.082 & 2.037 & 17.704 (1.98E-05) & $1.882(0.0012)$ \\
\hline 2018 & 0.158 & 0.257 & 2.985 & $18.916(0.0012)$ & $11.623(0.0044)$ \\
\hline
\end{tabular}

Authors' Computation, using STATA 14.2. Note: P-value in parenthesis. Due to the data structure, yearly values for 2009 and 2018 were computed between May 2009-Dec 2009 and Jan 2018-Jul 2018 respectively.

In conclusion, it appears that the Ghana stock, GDB and GFB market volatility are marching to different rhythms. Even though stock seems to be slightly more volatile than the bond, there is a tendency that the bond market can increase significantly over time particularly for the GFB.

\subsection{Correlation between bond and Stock return}

Figure 3 graphs the moving 3-month correlation coefficient of returns for Ghana Sovereign Bond (GDB and GFB) with GSE stock which also confirms a high level of volatility and instability over the period measured. In the case of the correlation between GDB to the stock return, the observations from the graph suggest that there were several periods when GDB rates of return were moving in the same direction to the stock rates of return. The trend slope coefficient is 0.00005 ( $\mathrm{p}=0.512$ ) but insignificant.

On the other hand, several periods of the rates of return of GFB were moving counter to the stock rates of return. The slope coefficient for the correlation between GFB and stock is $-0.000035(\mathrm{p}=0.661)$ but insignificant. Implying that the Ghanaian bond market remains an effective market for diversification.

Findings in the UK reported by Johnson and Young (2002) found a negative and insignificant correlation between the bond and stock return. Report from Switzerland (Young and Johnson, 2004) found a negative and significant correlation, while Reilly, Wright and Chan (2000) found a positive and significant correlation between the US bond and stock return.

\subsection{Daily market volatilities}

Because most financial returns exhibit random walk, we first explore stationary issues in the GDB, GFB and stock series. Table 5 presents the results from the stationarity test for the daily return series. In the case of the log GFB and $\log$ GDB, the null hypothesis of a unit root is rejected by the data regardless of whether the DF, ADF or PP was used for testing purposes. On the other hand, in the case of the log of stock daily return series, the null hypothesis of a unit root is not rejected by DF and ADF but is rather reject by PP. In the case of the 1st difference variables, the null hypothesis of a unit root in the data is rejected unambiguously with the use of either the DF, ADF and PP procedures. Implying stationarity at the first difference in $\log$ of all three daily series (i.e., mean-reverting). This is confirmed by further examination of their correlograms (plots not shown).

Table 5 Unit Root Tests for log of daily return Individual Series

\begin{tabular}{lrrrrrl}
\hline Test & GDB & GFB & Stocks & $\Delta_{1}$ GDB & $\Delta_{1}$ GFB & $\Delta_{1}$ Stocks \\
\hline DF (Test Statistics) & -1.548 & -2.115 & $-5.316^{* *}$ & $-37.312^{* *}$ & $-39.168^{* *}$ & $-17.151^{* *}$ \\
ADF (Test Statistics) & -1.573 & -2.553 & $-5.316^{* *}$ & $-22.788^{* *}$ & $-20.446^{* *}$ & $-28.824^{* *}$ \\
Phillips-Perron (PP) & -0.783 & -1.867 & -2.795 & $-37.337 * *$ & $-39.180^{* *}$ & $-3.440^{* *}$
\end{tabular}

Authors' Computation, using STATA 14.2.**Critical Value @ 0.05 level for DF and ADF $=-3.41$ in all cases. **Critical Value @ 0.05 level for $\mathrm{PP}=-2.860$ in all cases.

To inform on the issue of ARCH effects in all three series, we regress each stationary series on a constant only and no other variables using OLS. The OLS residuals are retrieved and Lagrange Multiplier (LM) ARCH test conducted using $1^{\text {st }}, 2^{\text {nd }}, 3^{\text {rd }}, 4^{\text {th }}$, and $5^{\text {th }}$ order lags. Table 6 illustrates the results of the ARCH-LM test for the log of daily return series 
with their respective test and p-values. The estimated effects for the moving average terms in the ARCH are well determined at the first, second, and third lag orders for the GFB, while that of the stock is only determined in the second and third lag orders. This confirms that GFB and stock are characterised by volatility clustering. To help inform market participants of the great value in the Ghanaian sovereign bond and stock assets, we apply the ARCH and GARCH models to the daily return series.

Table 6 Lagrange Multiplier (LM) test for autoregressive conditional heteroscedasticity (ARCH) for the log of daily returns series

\begin{tabular}{lccc}
\hline Lags & $\Delta_{1}$ GDB & $\Delta_{1}$ GFB & $\Delta_{1}$ Stock \\
\hline ARCH $\sim \chi_{1}^{2}$ & $0.019(0.8903)$ & $36.436(0.0000)$ & $0.318(0.5725)$ \\
ARCH $\sim \chi_{2}^{2}$ & $0.072(0.9646)$ & $38.933(0.0000)$ & $202.167(0.0000)$ \\
ARCH $\sim \chi_{3}^{2}$ & $0.368(0.9468)$ & $31.535(0.0000)$ & $91.769(0.0000)$ \\
ARCH $\sim \chi_{4}^{2}$ & - & - & $2.000(0.7358)$ \\
ARCH $\sim \chi_{5}^{2}$ & - & - & - \\
Sample Size & 2406 & 2406 & 2277 \\
\hline \multicolumn{2}{c}{ Authors' Computation, using STATA 14.2. P-value in parenthesis. }
\end{tabular}

Even though the LM test for the ARCH effect is not well determined at the first, second, and third lag orders for the GDB, the estimates for the ARCH(1) series did converge. Table 7 presents the result for the GDB ARCH (1) model. We show that volatility patterns in the GDB are very different from that of the GFB and stocks. The coefficient for the lagged-1 daily return period for the OLS and the ARCH(1) is positively significant. Suggesting that if the daily GDB volatility continues to display regular patterns over time, then future values could be forecast for the series using the ARCH(1) model. Again, the ARCH parameters $\left(\alpha_{0}, \alpha_{1}\right)$ are statistically significant at the one percent confident levels which suggests that the autoregressive conditional heteroscedasticity model fits the GDB daily volatility series well. This is an indication of volatility clustering. This finding also implies that the current period volatility in daily domestic bond return series in the Ghanaian market is related to the prior period. The $\operatorname{GARCH}(1,1)$ model for GDB series did not converge. Reilly, Wright and Chan, (2000) found similar results using the discrete annual standard deviation of the US bond market over1950-1999 period.

Table 7 Autoregressive models for log of daily Ghana Domestic bond return series from May 2009 - July 2018

\begin{tabular}{lccc}
\hline & Model 1 & Model 2 & Model 3 \\
Variables & OLS & ARCH $(1)$ & ARCH(1) AR(1) \\
\hline Lag 1 period & $0.0524^{* *}$ & & $0.126^{* * *}$ \\
& $(0.0254)$ & & $(0.0478)$ \\
L0.arch $\left(\alpha_{0}\right)$ & & $0.000553^{* * * *}$ & $0.000560^{* * *}$ \\
& & $(8.13 \mathrm{e}-05)$ & $(9.08 \mathrm{e}-05)$ \\
L1.arch $\left(\alpha_{1}\right)$ & & $0.112^{* * *}$ & $0.108^{* * *}$ \\
& & $(0.00865)$ & $(0.00969)$ \\
Constant & $0.000455^{* * *}$ & $9.64 \mathrm{e}-06^{* * *}$ & $9.61 \mathrm{e}-06^{* * *}$ \\
& $(8.89 \mathrm{e}-05)$ & $(5.59 \mathrm{e}-08)$ & $(5.58 \mathrm{e}-08)$ \\
Log likelihood & & 8302.815 & 8306.543 \\
AIC & & -16599.63 & -16605.09 \\
Observations & 1,438 & 1,921 & 1,921 \\
R-squared & 0.003 & & \\
\hline
\end{tabular}

Authors' Computation, using STATA 14.2. Standard errors in parentheses. $* * * \mathrm{p}<0.01, * * \mathrm{p}<0.05, * \mathrm{p}<0.1$.

The results of the daily return volatility series for the GFB is presented in Table 8. Again, they are markedly different from that of the GDB and stock volatility series. We note that the first lagged period for the OLS and GARCH $(1,1)$ models are not statistically significant. Telling that daily return volatility of the Ghana Eurobond series does not depend on the previous day's volatility because it does not exhibit regular patterns over time. 
Table 8 Autoregressive models for log of daily Ghana foreign bond return series from May 2009 - July 2018

\begin{tabular}{|c|c|c|c|}
\hline Variables & $\begin{array}{c}\text { Model } 1 \\
\text { OLS(GFB) }\end{array}$ & $\begin{array}{c}\text { Model } 2 \\
\text { ARCH(3) } \\
\end{array}$ & $\begin{array}{c}\text { Model 3 } \\
\text { GARCH }(1,1) \text { AR(1) }\end{array}$ \\
\hline Lag 1 period & $\begin{array}{l}-0.0143 \\
(0.0259)\end{array}$ & & $\begin{array}{l}-0.0483 \\
(0.0313)\end{array}$ \\
\hline L0. $\operatorname{arch}\left(\alpha_{0}\right)$ & & $\begin{array}{l}0.000239 * \\
(0.000134)\end{array}$ & $\begin{array}{l}-3.75 \mathrm{e}-06^{*} \\
(2.23 \mathrm{e}-06)\end{array}$ \\
\hline L1. $\operatorname{arch}\left(\alpha_{1}\right)$ & & $\begin{array}{l}0.356^{* * * *} \\
(0.0243)\end{array}$ & $\begin{array}{l}0.312 * * * \\
(0.0211)\end{array}$ \\
\hline L2 $\operatorname{arch}\left(\alpha_{2}\right)$ & & $\begin{array}{c}0.137 * * * \\
(0.0162)\end{array}$ & \\
\hline L3. $\operatorname{arch}\left(\alpha_{3}\right)$ & & $\begin{array}{r}0.274 * * * \\
(0.0184)\end{array}$ & \\
\hline $\operatorname{L1} \cdot \operatorname{garch}\left(\beta_{1}\right)$ & & & $\begin{array}{l}0.775 * * * \\
(0.0460)\end{array}$ \\
\hline Constant & $\begin{array}{c}0.000186 \\
(0.000205)\end{array}$ & $\begin{array}{c}1.79 \mathrm{e}-05^{* * * *} \\
(9.00 \mathrm{e}-07)\end{array}$ & $\begin{array}{l}-3.75 e-06^{*} \\
(2.23 e-06)\end{array}$ \\
\hline $\begin{array}{l}\text { Log likelihood } \\
\text { AIC }\end{array}$ & & $\begin{array}{l}6772.1341 \\
-13534.27\end{array}$ & $\begin{array}{l}6769.752 \\
-13529.5\end{array}$ \\
\hline Observations & 1,438 & 1,921 & 1,921 \\
\hline R-squared & 0.000 & & \\
\hline
\end{tabular}

When we consider the GARCH $(1,1)$ for the GFB series, the coefficient of the estimated variance parameters $\left(\alpha_{1}\right.$ and $\left.\beta_{1}\right)$ are significant. However, the coefficient of the estimated $\alpha_{0}$ is negative and statistically significant which violate the non-negative assumption $\left(\alpha_{0} \geq 0\right)$ of the model. This indicates that the $\operatorname{GARCH}(1,1)$ model does present a weak model for the Ghana Eurobond series and does not closely track the daily volatility return. We note that the ARCH(3) provides a better fit for the GFB daily volatility series. The ARCH(3) model shows that all the coefficients of the variance parameters $\left(\alpha_{0}, \alpha_{1}, \alpha_{2}\right.$, and $\left.\alpha_{3}\right)$ for the GFB daily series are positive and statistically significant. Signifying volatility clustering in the series by the conditional heteroscedastic model. Thus, the GFB market is inefficient. The analysis of the daily stock return volatility series is presented in Table 9. The first lagged value of the OLS is not significant.

However, the introduction of the $\operatorname{GARCH}(1,1)$ made the first lagged period significant. Additionally, the $\alpha_{0}, \alpha_{1}$ coefficients of the $\operatorname{GARCH}(1,1)$ model are all positively significant whiles the $\beta_{1}$ coefficient is negatively significant. This is also a violation of the non-negative assumption of the conditional heteroscedasticity model. Signifying that the GARCH(1,1) does not seem to closely mimic the Ghana stock market return volatility well. On the other hand, the $\operatorname{ARCH}(2)$ model seems to be a better fit for the stock series with only the $\alpha_{2}$ coefficient significant. This implies that the stock market is also inefficient. Again, similar to the GFB, we see that the stock return series does depend on previous volatility. Our findings agree with Gbeda and Peprah (2018) who assert that the GSE return information cannot be predicted. 
Table 9 Autoregressive models for log of daily stock return series from May 2009 - July 2018

\begin{tabular}{lccc}
\hline Variables & $\begin{array}{c}\text { Model 1 } \\
\text { OLS(Stock) }\end{array}$ & $\begin{array}{c}\text { Model 2 } \\
\text { ARCH(2) }\end{array}$ & $\begin{array}{c}\text { Model 3 } \\
\text { GARCH(1,1) } \\
\text { AR(1) }\end{array}$ \\
\hline Lag 1 period & -0.0220 & & $1.340^{* * *}$ \\
& $(0.0596)$ & & $(0.00455)$ \\
L0. $\operatorname{arch}\left(\alpha_{0}\right)$ & & 0.00668 & $0.000816^{* *}$ \\
& & $(0.0264)$ & $(0.000321)$ \\
L1. $\operatorname{arch}\left(\alpha_{1}\right)$ & & 0.00310 & $0.0552^{* * *}$ \\
& & $(0.00317)$ & $(0.00140)$ \\
L2. $\operatorname{arch}\left(\alpha_{2}\right)$ & & $0.0443^{* * *}$ & \\
L1.garch $\left(\beta_{1}\right)$ & & $(0.00266)$ & \\
& & & $-0.999 * * *$ \\
Constant & 0.00581 & $0.0361 * * *$ & $(5.36 \mathrm{e}-05)$ \\
& $(0.00747)$ & $(0.000314)$ & $\left(0.0678^{* * *}\right.$ \\
Log likelihood & & 393.02926 & 2912.959 \\
AIC & & -778.0585 & -5815.917 \\
Observations & 1,268 & 1,761 & 1,761 \\
R-squared & 0.000 & & \\
\hline Autors'Computat & & \\
\hline
\end{tabular}

\section{Conclusion}

$$
* * * \mathrm{p}<0.01, * * \mathrm{p}<0.05, * \mathrm{p}<0.1 \text {. }
$$

In this study, we analyze and document across 9-years from May 2009 - July 2018 changes in the Ghana sovereign domestic bond, Ghana sovereign foreign bond and stock market as epitomized by the S\&P Ghana Sovereign Bond Index return series and the Ghana Stock Exchange Composite total equity return series.

The results suggest that there are significant volatility swings across all asset classes over the period measured. In particular, the most substantial volatility was noticed in January 2013 and November 2014 for GDB and GFB respectively while that of the stock was observed in February and March 2011. Unlike the insignificant trend in volatility in the GFB, the trend in volatility for GDB and stock are negatively significant. The average monthly standard deviation for stocks return is about three times to the GFB and about five and a half times to the GDB. However, the average annual standard deviation for the stock is about two and a half times the average annual standard deviation for GDB and GFB. Potential investors who are interested in investing in these markets should, therefore, choose their asset base on how much risk they can take.

Further analysis confirms the instability between the GDB, GFB and Stock markets. The trend ratios in both GDB volatility and GFB volatility to stock market volatility has been relatively increasing with several periods well over the stock volatility. Nevertheless, there was no significant trend in bond to stock standard deviations. The average correlation between GDB and the stocks is about 0.220, while that of the GFB to the stocks is about 0.046.

We finally investigate the volatility clustering predictability of the bond/stock market daily series. The evidence suggests that the ARCH model can be used to explore volatility clustering and predict future values in GDB return series. However, it cannot be used to predict future values in the GFB and stock daily series. We document that all three asset classes are inefficient as they exhibit some form of volatility clustering. This research highlight some very important implications for asset allocation for the bond and stock markets in an emerging market. An investigation of the volatility of stocks and bonds in the light of inflation in developing markets would be an exciting research subject and we leave it for future studies.

\section{References}

Adelegan, O. J. and Radzewicz-Bak, B. (2009) 'What Determines Bond Market Development in Sub-Saharan Africa?', IMF Working Paper No. 09/213. DOI: 10.5089/9781451873603.001.

Adjasi, C. K. D. (2009) 'Macroeconomic uncertainty and conditional stock-price volatility in frontier African markets: Evidence from Ghana', Journal of Risk Finance, 10(4), pp. 333-349. DOI: 10.1108/15265940910980641.

Äijö, J. (2008) 'Implied volatility term structure linkages between VDAX, VSMI and VSTOXX volatility indices', Global Finance Journal, 18(3), pp. 290-302. DOI: 10.1016/j.gfj.2006.11.003. 
Alagidede, P. and Panagiotidis, T. (2006) 'Calendar anomalies in an emerging African market: evidence from the Ghana Stock Exchange', Loughborough University Institutional Repository emerging. Available at: https://dspace.lboro.ac.uk/dspace-jspui/bitstream/2134/2194/3/4082.pdf.

Andersen, T. G. et al. (2001) 'The distribution of realized stock return volatility', The Journal of Financial Economics, 63, pp. 43-76. DOI: 10.1016/j.jeconom.2010.07.008.

Angko, W. (2013) 'The Determinants of Stock Market Volatility in Ghana', Research Journal of Finance and Accounting, 4(13), pp. 146-166.

Arnold, I. J. M. and Vrugt, E. B. (2008) 'Fundamental uncertainty and stock market volatility', Applied Financial Economics, 18, pp. 1425-1440. DOI: 10.1080/09603100701857922.

Arnold, I. J. M. and Vrugt, E. B. (2010) 'Treasury Bond Volatility and Uncertainty about Monetary Policy', The Financial Review, 45, pp. 707-728.

Bessembinder, H. (2018) 'Do stocks outperform Treasury bills?', Journal of Financial Economics, 129(3), pp. 440457. DOI: $10.1016 /$ j.jfineco.2018.06.004.

Bretscher, L., Schmid, L. and Vedolin, A. (2016) 'Interest Rate Uncertainty, Hedging, and Real Activity', SSRN Electronic Journal. DOI: 10.2139/ssrn.2716993.

Castanias II, R. P. (1979) 'Macroinformation and the Variability Of Stock Market Prices', Journal of Finance, 34(2), pp. 439-450. DOI: 10.1111/j.1540-6261.1979.tb02107.x.

Creal, D. D. and Wu, J. C. (2014) 'Interest Rate Uncertainty and Economic Fluctuations', SSRN Electronic Journal. DOI: $10.2139 / \mathrm{ssrn} .2504590$.

Dafe, F., Essers, D. and Volz, U. (2018) 'Localising sovereign debt: The rise of local currency bond markets in subSaharan Africa', World Economy. DOI: 10.1111/twec.12624.

Engle, R. (2001) 'GARCH 101: The Use of ARCH/GARCH Models in Applied Econometrics', Journal of Economic Perspectives, 15(4), pp. 157-168. DOI: 10.1257/jep.15.4.157.

Essers, D. et al. (2014) 'Local currency bond market development in Sub-Saharan Africa: A stock-taking exercise and analysis of key drivers', SSRN. Available at: https://ssrn.com/abstract=2533824.

Fisher, L. and Lorie, J. H. (1970) 'Some Studies of Variability of Returns on Investments in Common Stocks', The Journal of Business, 43(2), pp. 95-134. Available at: http://www.jstor.org/stable/1826387.

Frimpong, J. M. and Oteng-Abayie, E. F. (2006) 'Modelling and Forecasting Volatility of Returns on the Ghana Stock Exchange Using GARCH Models', American Journal of Applied Sciences, 3(10), pp. 2042-2048. DOI: 10.3844/ajassp.2006.2042.2048.

Gbeda, J. M. and Peprah, J. A. (2018) 'Day of the week effect and stock market volatility in Ghana and Nairobi stock exchanges', Journal of Economics and Finance, 42(4), pp. 727-745. DOI: 10.1007/s12197-017-9409-7.

Gevorkyan, A. V. and Kvangraven, I. H. (2016) 'Assessing Recent Determinants of Borrowing Costs in Sub-Saharan Africa', Review of Development Economics, 20(4), pp. 721-738. DOI: 10.1111/rode.12195.

Giot, P. (2005) 'Relationships Between Implied Volatility Indexes and Stock Index Returns. Are implied volatility indexes leading indicators?', The Journal of Portfolio Management, 31(3), pp. 92-100. DOI: $10.3905 / \mathrm{jpm} .2005 .500363$.

Gonzalez, M. T. and Alfonso, N. (2009) 'Are volatility indices in international stock markets forward looking?', RACSAM, 103(2), pp. 339-352.

Jaramba, T. and Fadiran, G. (2009) Analysis of volatility transmission across South African Financial Markets, MPRA Paper No. 77769. Available at: https://mpra.ub.uni-muenchen.de/77592/1/MPRA_paper_77592.pdf.

Johnson, R. and Young, P. (2002) 'Bond Market volatility compared with stock market volatility: Evidence from the UK', Journal of Asset Management, 3(2), pp. 101-111. DOI: 10.1057/palgrave.jam.2240069.

Jones, B., Lin, C. T. and Masih, A. M. M. (2005) 'Macroeconomic announcements, volatility, and interrelationships: An examination of the UK interest rate and equity markets', International Review of Financial Analysis, 14(3), pp. 356-375. DOI: 10.1016/j.irfa.2004.10.001.

Jones, C. M., Lamont, O. and Lumsdaine, R. L. (1998) 'Macroeconomic news and bond market volatility', Journal of Financial Economics, 47, pp. 315-337.

Jones, C. P. and Wilson, J. W. (2004) 'The Changing Nature of Stock and Bond Volatility', Financial Analysts Journal, 60(1), pp. 100-113.

King, D. and Botha, F. (2015) 'Modelling stock return volatility dynamics in selected African markets', Economic Modelling, 45, pp. 50-73. DOI: 10.1016/j.econmod.2014.11.008.

Konstantinidi, E., Skiadopoulos, G. and Tzagkaraki, E. (2008) 'Can the evolution of implied volatility be forecasted? Evidence from European and US implied volatility indices', Journal of Banking and Finance, 32(11), pp. 2401-2411. DOI: 10.1016/j.jbankfin.2008.02.003. 
Lin, B., Wesseh, P. K. and Appiah, M. O. (2014) 'Oil price fluctuation, volatility spillover and the Ghanaian equity market: Implication for portfolio management and hedging effectiveness’, Energy Economics. Elsevier B.V., 42, pp. 172-182. DOI: 10.1016/j.eneco.2013.12.017.

Liu, H. H., Wang, T. K. and Li, W. (2019) 'Dynamical Volatility and Correlation among US Stock and Treasury Bond Cash and Futures Markets in Presence of Financial Crisis: A Copula Approach', Research in International Business and Finance, 48, pp. 381-396. DOI: 10.1016/j.ribaf.2019.02.002.

López, R. (2015) 'Do stylized facts of equity-based volatility indices apply to fixed-income volatility indices? Evidence from the US Treasury market', International Review of Financial Analysis, 42, pp. 292-303. DOI: 10.1016/j.irfa.2015.08.005.

Officer, R. R. (1973) 'The Variability of the Market Factor of the New York Stock Exchange', The Journal of Business, 46(3), pp. 434-453.

Olabisi, M. and Stein, H. (2015) 'Sovereign bond issues: Do African countries pay more to borrow?', Journal of African Trade, 2(1), pp. 87-109. DOI: 10.1016/j.joat.2015.08.003.

Pan, Z. and Chan, K. F. (2018) 'A new government bond volatility index predictor for the U.S. equity premium', Pacific Basin Finance Journal, 50, pp. 200-215. DOI: 10.1016/j.pacfin.2016.12.007.

Presbitero, A. F. et al. (2016) 'Sovereign bonds in developing countries: Drivers of issuance and spreads', Review of Development Finance, 6(1), pp. 1-15. DOI: 10.1016/j.rdf.2016.05.002.

Rapach, D. E., Wohar, M. E. and Rangvid, J. (2005) 'Macro variables and international stock return predictability', International Journal of Forecasting, 21(1), pp. 137-166. DOI: 10.1016/j.ijforecast.2004.05.004.

Reilly, F. K., Wright, D. J. and Chan, K. C. (2000) 'Bond Market Volatility Compared to Stock Market Volatility. Critical effects for asset allocation.', The Journal of Portfolio Management, pp. 82-92.

Saleem, K. et al. (2014) 'Market Integration, Return and Volatility Dynamics: Empirical Evidence from African Stock Markets', International Business Research, 7(9), pp. 30-44. DOI: 10.5539/ibr.v7n9p30.

Segal, G. (2019) 'A Tale of Two Volatilities: Sectoral Uncertainty, Growth, and Asset Prices', Journal of Financial Economics. DOI: 10.1016/j.jfineco.2019.03.002.

Senga, C. and Cassimon, D. (2018) Spillovers in Sub- Saharan Africa's sovereign Eurobond yields, Working Paper No. 24. Available at: http://www.befind.be/Documents/WPs/wp24.

Senga, C., Cassimon, D. and Essers, D. (2018) 'Sub-Saharan African Eurobond yields: What really matters beyond global factors?', Review of Development Finance, 8, pp. 49-62. DOI: 10.1016/j.rdf.2018.05.005.

Sharpe, W. F. (1973) 'Bonds versus Stocks: Some Lessons from Capital Market Theory', Financial Analysts Journal, 29(6), pp. 74-80. DOI: 10.2469/faj.v29.n6.74.

Siriopoulos, C. and Fassas, A. (2012) 'An investor sentiment barometer - Greek Implied Volatility Index (GRIV)', Global Finance Journal. Elsevier Inc., 23(2), pp. 77-93. DOI: 10.1016/j.gfj.2012.03.001.

Su, Z., Fang, T. and Yin, L. (2018) 'Understanding stock market volatility: What is the role of U.S. uncertainty?', North American Journal of Economics and Finance. DOI: 10.1016/j.najef.2018.07.014.

Whaley, R. E. (2009) 'Understanding the VIX', The Journal of Portfolio Management, 35(3), pp. 98-105. DOI: 10.3905/jpm.2009.35.3.098.

Young, P. J. and Johnson, R. R. (2004) 'Bond Market Volatility vs. Stock Market Volatility: The Swiss Experience', Financial Markets and Portfolio Management, 18(1), pp. 8-23. DOI: 10.1007/s11408-004-0102-4. 